УДК 355.233:316.422(477)

Тетяна Ворона,

Національний університет оборони України імені Івана Черняховського, м. Київ

ORCID ID 0000-0001-5544-3341

Анна Ворона,

Національний університет оборони України імені Івана Черняховського, м. Київ

ORCID ID 0000-0002-4910-2249

DOI: $10.33099 / 2617-1775 / 2021-02 / 43-50$

\title{
ОСОБЛИВОСТІ МОДЕРНІЗАЦІЇ МОВНОЇ ОСВІТИ В ЗБРОЙНИХ СИЛАХ УКРАЇНИ
}

Статтю присвячено модернізачії мовної освіти дорослих у Збройних Силах України. Основна увага зосереджена на розвитку іншомовної комунікащії, як важливої складової професійного рівня військовослужбовиів. У статті підкреслюється, що курс на євроінтеграцію й зближення із Європейським Союзом супроводжується формуванням загального освітнього й наукового простору, розробкою єдиних критерїв і стандартів, $у$ тому числі й щодо вивчення мов. Перебуваючи в тісній співпраці із зарубіжними колегами, військові фахівиі Збройних сил України мають не лише впроваджувати євроатлантичні стандарти в практику украӥнської армії, а й праџювати над рівнем взаємосумісності зі збройними силами держав - членів і партнерів НАТО, що передбачає належне вивчення мов міжнародного співробітництва.

Ключові слова: мовна освіта в Збройних Силах Украӥни; модернізація мовної освіти; професійна взаємодія; мовна взаємосумісність.

Постановка проблеми. Сьогодні в світі важко знайти державу, влада б якої відверто не сповідувала принципи демократії. Навіть самі авторитарні політичні режими декларують у основі своїх політик законність, розуміння та цивілізоване вирішення проблем. Від так ключовими основами відтворення демократичних принципів $€$ порозуміння та довіра, в яких основну роль відіграє рівень освіти та ключові вміння комунікувати на засадах взаємоповаги та взаємовизнання.

Друга світова війна принесла величезні зміни в життя всього людства. Але одним із найбільших позитивних іiі наслідків стало руйнування колоніальної системи світу. Саме тому із кінця 40-х років XX століття почали відкриватися кордони й соціальна карта світу дуже змінила свої обриси. Міграційні процеси, переміщення капіталів, подекуди взаємовпливи культур - все це призводить до налагодження практики міжкультурного спілкування й встановлення певних правил міжкультурного діалогу.

$\mathrm{Hi}$ в якому випадку не заперечуючи філософію концепцій «мовної ідентичності», збереження національної культури, із середини XX століття починає втілюватися в практику концепція «мовної багатоманітності та розбудови інтеркультурного суспільства». Iз формуванням поняття «міжкультурний вибір» дослідження набуває проблема мовної освіти дорослих, саме в частині іншомовної підготовки.

Аналіз останніх досліджень і публікацій. Проблема іншомовної освіти 
дорослих є в фокусі уваги багатьох вітчизняних та зарубіжних дослідників. Уміння володіти іноземною мовою, окрім рідної, $є$ однією із ключових компетентностей людини XXI століття та фахівця будь-якої сфери. Якщо узагальнити праці Л. Вікторової, Т. Десяткового, М. Дреєрмана, О. Коротун, О. Лазаренко, О. Максименко, Н. Махині, М. Пархомчук, Л. Пуховської, М. Тадеєвої, О. Яковлевої, то можна прийти висновку, що саме розвиток іншомовної освіти є одним із вагомих механізмів досягнення професійного розвитку фахівця, гарантування громадянського прогресу та демократичного устрою суспільного життя.

Численні дослідження зарубіжних науковців підкреслюють, що питання вивчення мов (тут ми беремо за увагу мови міжнародного спілкування англійську, меншою мірою німецьку чи французьку) допомагають розширювати спектр індивідуальних, соціальних, професійних та кар'єрних можливостей дорослих, встановлювати й розвивати міжособистісні, міжкультурні контакти та отримувати нові компетентності [1, с. 23]. Це стосується й освіти військовослужбовців Збройних сил України.

Постійно працюючи над професійним рівнем військовослужбовців Збройних сил України, це питання особливо стає у фокусі уваги із 2014 року, коли Україна зіткнулася із проблемами зовнішньої агресії зі сторони сусідів. Досліджуючи питання мовної взаємосумісності та вивчення іноземних мов, у своїх наукових розвідках Семенов Ю., Сиромля Ю. зазначають, що взаємодія 3 військовими формуваннями міжнародних організацій та країн-партнерів у рамках реалізації заходів міжнародного співробітництва, а це й участь у міжнародних миротворчих операціях під егідою ООН чи НАТО, у роботі багатонаціональних штабів тощо, прямо передбачає знання мови міжнародного спілкування [2, с. 81$]$.

Курс на євроінтеграцію й зближення із Європейським Союзом супроводжується формуванням загального освітнього й наукового простору, розробкою єдиних критеріїв і стандартів, у тому числі й щодо вивчення мов. Рамковим документом, який у доступній формі описує, чого мають навчитися ті, хто оволодіває мовою, щоб користуватися нею для спілкування, та які знання й вміння їм потрібно розвивати, щоб діяти ефективно, $\epsilon$ «Загальноєвропейські Рекомендації з мовної освіти: вивчення, викладання, оцінювання» [3].

Метою статті $\epsilon$ аналіз проблем i тенденцій щодо особливостей модернізації мовної освіти в Збройних силах України.

Виклад основного матеріалу дослідження. Ведення діалогу розглядається як явище, яке має одне із основних значень для становлення й розвитку демократичних процесів у культурно багатоманітних суспільствах. У цьому випадку фундаментальним принципом демократії виступає вміння висловлювати власні погляди під час ухвалення політичних рішень. Проте, відповідно дзеркальним вмінням, є таке, що передбачає критично слухати й дослухатися до висловленого. Таким чином, діалог - це єдиний найважливіший спосіб висловлювання думок, прагнень, рішення проблем та забезпечення потреб для представників різних культур. А це означає, що в культурно 
багатоманітних суспільствах ведення такої комунікації $є$ вирішальним для демократичної дискусії, дебатів, обговорень, надання учасникам рівних можливостей впливати на ухвалення політичних рішень на рівноправних умовах. I тому сам діалог має вестися зрозумілою для всіх мовою.

Ми суголосні із думкою тих дослідників, що вивчаючи іноземну мову, людина отримує не лише знання іншої мови, а й долучається до найціннішого іншого народу - його культури [4]. I в цьому аспекті іншомовна освіта спрямована на духовне збагачення й удосконалення особистості через діалог власної та суспільно визнаної комунікації. Саме тому, розглядаючи вивчення інших мов через компетентнісний підхід, можна зазначити, що цей процес, по суті, включає чотири етапи:

- навчання, націлене на оволодіння соціальним змістом іншомовної культури, тобто мовними вміннями, які засвоюються як засоби спілкування в соціумі;

- пізнання, що направлене на оволодіння культурологічним змістом іншомовної культури, тобто культурою країни, фактами культури й мовою як частиною культури;

- розвиток та отримання досвіду, направлені на оволодіння психологічним змістом іншомовної культури (здібності, психічні функції тощо);

- виховання, що націлене на оволодіння педагогічним змістом іншомовної культури (етичний та моральний аспекти) [4, с. 174].

Вивчаючи іноземні мови, варто орієнтуватися на певні рамкові мовні знання та ступінь сформованості мовленнєвих навичок і вмінь. Тобто сьогодні вже не можна зупинятися лише на знаннєвій складовій освіти. Її предметно заміняє компетентнісна складова. У Збройних силах України такий рівень оцінюється за шкалою стандартизованих мовленнєвих рівнів (СМР), які відповідають рівням мовленнєвої компетенції за мовним стандартом НАТО СТАНАГ 6001 [5].

Міністерство оборони України проводить цілеспрямовану політику за для досягнення Цілей партнерства Україна - НАTO G1200 «Мовні вимоги» (на 2019 - 2024 роки) відповідно до стандарту HATO STANAG 6001 та Основних засад мовної підготовки особового складу у системі відомства, впровадження нових кваліфікаційних вимог щодо рівнів володіння іноземною мовою, визначених у каталозі посад офіцерського (сержантського, старшинського складу), єдиної навчальної програми «Іноземна мова» у вищих військових навчальних закладах, інтенсифікації співпраці з урядом США в рамках проєкту 3 облаштування нових мовних лабораторій [5]. I в цих вимірах навчання іноземну мову передбачено знати за 4 основними видами мовленнєвої діяльності: аудіювання, говоріння, читання, письмо.

У своїх наукових розвідках ми вже окреслювали проблему рівня володіння рідною мовою, як важливої навички фахівця-військовослужбовця. Проте, якщо піднімати рівень рідної мови можливо через пізнання національної культурної спадщини (вивчення народних пісень, казок, приказок, інших жанрів усної народної творчості; читання художніх творів-класиків та ін.), то вивчення 
іноземних мов $\mathrm{i}$ робота над іншомовним комунікативним рівнем має починатися із теоретичного аспекту: заучування слів та розширення словникового запасу. Але в цьому ракурсі варто звернути увагу на інтегрований принцип вивчення мов, адже кожна мова, як певний «культурний код нації», несе пізнання особливостей характеру іншомовної культури.

Сама інтеграція попереджає звичний «дослівний» переклад. Для прикладу, англійський термін «intelligence» у військовій сфері означає «розвідка», проте у словосполученні «airborne artificial intelligence» цей термін перекладається як «бортова система штучного розуму». Саме тому варто звертати увагу не на просте заучування слів чи словосполучень, а й на їх варіанти перекладу й практичного застосування. Іншими словами, зміст й методи навчання іншомовної освіти мають бути сучасними, а не залишатися на рівні радянської системи - «уміння читати й перекладати із словником».

Враховуючи, що у «Загальноєвропейських Рекомендаціях із мовної освіти: вивчення, викладання, оцінювання» [3] визначено кілька рівнів володіння мовою - від А (розмовного) до С (вільного, професійного), то мовна освіта базується на певних принципах. У цьому ракурсі ми б хотіли означити наступне. Іншомовна освіта для військовослужбовці має викладатися із врахуванням:

— системності й послідовності;

— гнучкості й прогностичності;

— безперервності й багатоманітності.

Як правило, найкраще засвоюється мова, коли є мовне середовище, працює носій мови або є робота над професійно-орієнтованим текстом. За таких умов та в поєднанні із сучасними методиками навчання рівень оволодіння іноземною мовою буде достатньо високим. Хоча важливо врахувати й наступні особливості: не аби яке значення в будь-якому навчанні відіграє рівень мотивації здобувача освіти та вміння організувати самостійне навчання.

Мотиваційні процеси, якими має керуватися військовослужбовець, повністю переплітаються із особливостями розвитку психологічної готовності до іншомовного спілкування. Досліджуючи ці питання, науковець О. Лагодинський звертає увагу на те, що комунікативний характер фахової діяльності випускників закладів вищої військової освіти України вимагає від них не лише високого рівня володіння іноземною мовою для іншомовного спілкування, а й певного набору вольових рис характеру. Адже таке спілкування може відбуватися в умовах екстремальних видів діяльності та емоційного стресу [6, с. 179]. Саме тому мотивація й вміння керувати власними емоціями під час екстремальних умов - надзвичайно важливі емоційно-вольові компоненти мовної освіти, які мають опанувати військовослужбовці Збройних сил України.

У своєму дослідженні також зупинимося на навчально-методичних підходах щодо вивчення мов.

Враховуючи той факт, що військовослужбовці вже мають хоча б початковий рівень іншомовної підготовки, варто звернути увагу на використання методик, які базуються на принципі концентричного 
пред'явлення тематичного матеріалу для організації спілкування в усній та письмовій формі. У зв'язку з цим одна і та ж тема може вивчатися впродовж кількох років, поглиблюючись до такого рівня, якого вимагатимуть професійні рамки володіння мовою.

Під час навчання мовам варто звертати увагу на використання в освітній практиці особистісно зорієнтованих та діяльнісних методик. Такі методичні прийоми дозволять не лише механічно оволодіти професійним тезаурусом, а й паралельно працювати над розвитком власної комунікативної компетентності, критичним та креативним мисленням, гнучкістю та мобільністю мовного мислення. Як приклад, назвемо використання вправ «читання тексту із зупинками», гронування / кубування, синквейн, «фішбоун» («рибна кістка»), кубик Блума, прогнозування за ілюстрацією, сторітеллінг та ін.

Використання ігрових методик, особливо дидактичних та пізнавальнонавчальних ігор, дозволить у саме навчання додати рівня зацікавленості та отримати відчуття неперевантаженості новими знаннями.

Вивчаючи мови, не можна сьогодні обійтися без сучасних IКТ-засобів навчання. Це сукупність методів, засобів та прийомів пошуку, зберігання, опрацювання, подання та передавання графічних, текстових, цифрових, аудіо та відеоданих на базі персональних комп'ютерів, комп'ютерних мереж та засобів зв'язку. Різноманітні текстові редактори, СМАРТ-технології, геосервіси, освітні електронні видання, мовні тренажери тощо - все це може дієво допомогти вивчити іноземну мову на професійному рівні.

ІКТ-засобів навчання здійснюють активний вплив не лише на процес мовного навчання, а й змінюють саму схему передавання інформації, таким чином модернізуючи освітні технології. Використання електронних підручників і мультимедіа; електронних бібліотек i архівів, глобальних та локальних освітніх мереж; інформаційно-пошукових та інформаційнодовідкових систем, дозволяють фахівцям у військовій сфері мобільніше працювати й виконувати свої професійні обов'язки як гарантів миру й безпеки на планеті Земля.

Висновки i перспективи подальших досліджень. Мовна освіта й вивчення іноземних мов, як іiі одна із складових, $\epsilon$ важливим чинником у розвитку й становленні особистості. Володіння іноземними мовами особовим складом є важливим чинником ефективного реформування та подальшого розвитку Збройних сил України, успішного впровадження євроатлантичних стандартів задля досягнення українською армією взаємосумісності зі збройними силами держав - членів і партнерів НАТО, забезпечення належної участі у багатонаціональних операціях, навчаннях, інших заходах міжнародного оборонного співробітництва.

У своєму дослідженні ми звернули увагу на компетентнісну складову мовної освіти військових фахівців Збройних сил України, особливості комунікації іноземними мовами. У висновках ми можемо вказати, що знання іноземних мов / або хоча б однієї такої мови є надзвичайно важливим фактором професійного рівня військовослужбовця. Адже це

— готовності фахівця до міжнародної взаємодії на паритетних умовах; 
- здатність до оперативного виконання поставлених завдань із дотриманням найбільш ефективних шляхів вирішення;

- засвоєння норм та еталонів іншомовної діяльності;

— гнучкість та мобільність мислення (на основі рефлексіі);

- здатність до професійного та особистісного самовдосконалення;

- розвиток комунікативних та комунікативно-технологічних знань i вмінь, необхідних для забезпечення позитивного результату діяльності, розвиненість умінь аналізувати та прогнозувати свій професійнокомунікативний розвиток;

- здатність до постійного накопичення професійного досвіду, його збагачення через участь у різних видах творчої фахової діяльності та передача колегам своїх професійних знань;

- кооперативність, конструктивна реакція та поведінка у конфліктних ситуаціях тощо.

Сформованість і розвиток зазначених умінь та якостей, а також їхній синергізм в особистості військового фахівця визначають основу його готовності до професійної взаємодії в іншомовному середовищі для виконання свого соціально значущого професійного обов’язку 3 підтримання миру i безпеки.

Проведене дослідження не вичерпує всіх аспектів проблеми дослідження. Перспективними напрямками подальших розвідок ми вбачаємо вивчення досвіду зарубіжних фахівців щодо розроблення інтегрованих мовних індивідуальних програм із підвищення рівнів мовної компетентності військовослужбовців Збройних сил України.

\section{ЛІТЕРАТУРА}

1. Вікторова, Л. В. Організаційні засади та зміст фахової іншомовної підготовки у Франції. Педагогічні науки. Збірник наукових праць. 2016. Вип. LXIX. Том 2. C. 23-27.

2. Семенов, Ю.М., Сиромля, Ю.П. Забезпечення мовної взаємосумісності з військовими формуваннями міжнародних організацій. Вісник Національної академії оборони. 2010. Вип. 3 (16). C. 81-84.

3. Загальноєвропейські Рекомендації 3 мовної освіти: вивчення, викладання, оцінювання. Київ : Ленвіт, 2003. 273 с.

4. Коротун, О. О. Сучасні підходи до іншомовної підготовки різних категорій дорослих у процесі неформальної освіти. Міжнародний філологічний часопис № 263 2017p. С. 172-179.

5. Наказ Міністерства оборони України від 13 грудня 2016 року № 692 «Про затвердження Критеріїв використання іноземної мови у службовій діяльності військовослужбовцями Збройних Сил України» URL: https://www.mil.gov.ua/diyalnist/vijskova-osvita-na-tauka/\#movna (дата звернення 29.08.2020).

6. Лагодинський О. С. Розвиток психологічної готовності до іншомовного спілкування майбутніх фахівців як предмет наукового аналізу. Стратегії міжкультурної комунікації в мовній освіті сучасного ВНЗ : тези Міжнар. наук.-практ. конф. (м. Київ, 3 бер. 2016 р.) / Київський нац. екон. ун-т ім. Вадима Гетьмана. Київ, 2016. С. 179-182.

\section{REFERENCES}

1. Viktorova, L.V. Organizational principles and content of professional foreign language training in France. Pedagogical sciences. Collection of scientific works. 2016. Vip. LXIX. Volume 2. pp. 23-27. 
2. Semenov, Yu. M., Siromlya, Yu. P. Ensuring linguistic interoperability with military formations of international organizations. Bulletin of the National Defense Academy. 2010. Vip. 3 (16). Pp. 81-84.

3. Pan-European Recommendations on language education: study, teaching, assessment. Kyiv: Lenvit, 2003. 273 p.

4. Korotun, O.O. Suchasni pidkhody do inshomovnoi pidhotovky riznykh katehorii doroslykh u protsesi neformalnoi osvity. Mizhnarodnyi filolohichnyi chasopys № 263 2017r. S. 172-179.

5. Order of the Ministry of Defense of Ukraine of December 13, 2016 № 692 «On approval of the Criteria for the use of a foreign language in official activities by servicemen of the Armed Forces of Ukraine» Retrieved, from 29.08.2020 https://www.mil.gov.ua/diyalnist/vijskova-osvitana-tauka/\#movna

6. Lagodynsky, O. S. Development of psychological readiness for foreign language communication of future specialists as a subject of scientific analysis. Strategies of intercultural communication in language education of modern universities: abstracts International. scientific-practical conf. (Kyiv, March 3, 2016) / Kyiv National University. econ. Univ. Vadim Hetman. Kyiv, 2016. S. 179-182.

\section{PЕЗЮМЕ}

Татьяна Ворона

Национальный университет обороны Украины имени Ивана Черняховского

Анна Ворона

Национальный университет обороны Украины имени Ивана Черняховского

\section{Особенности модернизации языкового образования в Вооруженных силах Украины}

Статья посвящена модернизащии языкового образования взрослых в Вооруженных Силах Украины. Основное внимание сосредоточено на развитии иноязычной коммуникации, как важной составляющей профессионального уровня военнослужаших. $B$ статье подчеркивается, что курс на евроинтеграчию и сближение с Европейским Союзом сопровождается формированием общего образовательного и научного пространства, разработкой единых критериев и стандартов, в том числе и по изучению языков. Находясь в тесном сотрудничестве с зарубежными коллегами, военные специалисты Вооруженных Сил Украинь должны не только внедрять евроатлантические стандарты в практику украинской армии, но и работать над уровнем совместимости с вооруженными силами государств - членов и партнеров НАТО, что предусматривает надлежащее изучение языков международного сотрудничества.

Ключевые слова: языковое образование в Вооруженных Силах Украины; модернизация языкового образования; профессиональное взаимодействие; языковая совместимость.

\section{SUMMARY}

Tetiana Vorona,

National Defence University of Ukraine named after Ivan Cherniakhovskyi

Anna Vorona,

National Defence University of Ukraine named after Ivan Cherniakhovskyi 


\section{Modernization features of language education in the Armed Forces of Ukraine}

Abstract. The key foundations for the reproduction of democratic principles are understanding and trust, in which the level of education and key skills to communicate on the basis of mutual respect and mutual play the main role.

The Second World War brought enormous changes in the life of all mankind but one of its most positive consequences was the destruction of the colonial system of the world. That is why, from the end of the 40s of the twentieth century, borders began to open and the social map of the world has significantly changed its shape. Migration processes, capital movements, sometimes mutual cultures - all this leads to the establishment of the practice of intercultural communication and the establishment of certain rules for intercultural dialogue.

In no way denying the philosophy of the concepts of "linguistic identity", the preservation of national culture, from the middle of the twentieth century, the concept of "linguistic diversity and the development of an intercultural society" began to be embodied in practice. With the formation of the concept of "intercultural choice", the study acquires the problem of language education for adults, namely in terms of foreign language training.

Purpose. Analysis of problems and trends regarding the features of modernization of language education in the Armed Forces of Ukraine.

Methods. At different stages of scientific research, the following methods were used: theoretical - analysis, synthesis, generalization, comparison and systematization of regulatory documents, scientific research and literature, educational and methodological documentation, the experience of professional training of cadets and the participation of officers of the Armed Forces of Ukraine in peacekeeping operations; empirical (research of issues of language education of adults in the Armed Forces of Ukraine).

Results. Considering the study of other languages through a competence-based approach, it can be determined that this process, in fact, includes four stages:

- training aimed at mastering the social content of a foreign language culture, that is, speech skills that are acquired as a means of communication in society;

- knowledge aimed at mastering the cultural content of a foreign language culture, that is, the culture of the country, the facts of culture and language as part of culture;

- development and gaining experience aimed at mastering the psychological content of a foreign language culture (abilities, mental functions, etc.);

- education, aimed at mastering the pedagogical content of a foreign language culture (moral and moral aspects).

And as a result, we can indicate that knowledge of foreign languages / or at least one such language is an extremely important factor in the professional level of military personnel.

Originality. Speech is best absorbed when there is a language environment, a native speaker is working, or when working on a professionally oriented text. Under such conditions and in combination with modern teaching methods, the level of mastering a foreign language will be quite high. Although it is important to take into account the following features: not anyhow, what importance does the level of motivation of the applicant for education and the ability to organize self-study play in any training.

Conclusion. The formation and development of these skills and qualities, as well as their synergy in the personality of a military specialist, determine the basis of his readiness for professional interaction in a foreign language environment to fulfill his socially significant professional duty to maintain peace and security.

Key words: language education in the Armed Forces of Ukraine; modernization of language education; professional interaction; language compatibility. 